Original Research Paper

\title{
Draft Genome of Lysinibacillus sphaericus Isolate 229C Pathogenic to Vector Mosquitoes
}

\author{
Afiannisa Viersanova ${ }^{1} \&$ Hari Purwanto ${ }^{1 *}$ \\ ${ }^{1}$ Departemen Biologi tropika, Fakultas Biologi, Universitas Gadjah Mada, Yogyakarta, Indonesia.
}

\author{
Article History \\ Received : July 02 ${ }^{\text {th }}, 2021$ \\ Revised : July $13^{\text {th }}, 2021$ \\ Accepted : July $15^{\text {th }}, 2021$ \\ Published : July $18^{\text {th }}, 2021$ \\ *Corresponding Author: \\ Hari Purwanto, \\ Departemen Biologi Tropika, \\ Fakultas Biologi, Universitas \\ Gadjah Mada, Yogyakarta, \\ Indonesia. \\ Email: \\ hari.purwanto@ugm.ac.id
}

\begin{abstract}
Lysinibacillus sphaericus is widely known as a bioinsecticide agent because it shows entomopathogenic activity against vector mosquitoes, especially of Culex and Anopheles spp. This bacterium known to have variations in toxicity. Its binary toxins, which is known to have a high toxicity, has a very low genetic variation, so that resistance problems has been reported. Therefore, exploration continues to be carried out to find a new effective and potential toxin to deal with the resistance problems. This study aims to analyze the genome of isolate 229C L. sphaericus, to identify the species of isolate 229C based on the $16 \mathrm{~S}$ rRNA gene, and to identify toxin characteristics of the $229 \mathrm{C}$ isolate based on the results of genome sequence analysis. The $229 \mathrm{C}$ isolate was previously obtained from soil sample in Indonesia and showed a high pathogenicity against $C$. quenquefasciatus. Molecular identification was carried out with the $16 \mathrm{~S}$ rRNA gene analysis. While draft genome and toxin analysis performed by conducting whole genome sequencing using Illumina Hiseq 2000, 250 bp pair-end protocol. The sequenced data then analized using freely available bioinformatics tools. The results of the molecular identification showed that the closest related species of isolate $229 \mathrm{C}$ was L. sphaericus. The isolate 229C has a genome size of $4.65 \mathrm{Mbp}$ and $\mathrm{G}+\mathrm{C}$ content of $36.83 \%$. Toxin analysis showed that this isolate did not contain Mosquitocidal toxin (Etx/Mtx), binary toxin (Bin protein), crystal toxin (Cry48/Cry49 protein), nor Sphaericolysin genes. However, there are s-layer protein and hemolysin genes that also known to be associated with the toxicity of $L$. sphaericus to mosquitoes and possibly, are the answer to the problem of resistance to binary toxins. This result opens the opportunity for an analysis of the effectiveness of S-layer protein and Hemolysin against resistance population mosquitoes.
\end{abstract}

Keywords: Draft Genome; Hemolysin; Lysinibacillus sphaericus; Slayer protein; Vector mosquitoes.

\section{Pendahuluan}

Lysinibacillus sphaericus pertama kali diisolasi dari larva instar 4 Culiseta incidens di Fresno, California (Kellen et al., 1965). Studi yang dilakukan setelahnya menunjukkan spesifisitas yang tinggi dari aktivitas entomopatogen bakteri ini terhadap nyamuk Culex dan Anopheles spp. Oleh karena itu, hingga saat ini $L$. sphaericus dikenal dan digunakan secara luas sebagai bioinsektisida dan merupakan bagian dari program pengendalian vektor penyakit tropis infeksius (Berry, 2012).
Aktivitas entomopatogen dari $L$. sphaericus disebabkan oleh keberadaan toxin yaitu Mosquitocidal toxin (Mtx protein), Binary toxin (BinA-BinB), Crystal toxin (Cry48/Cry49), S-layer protein, dan Hemolysin (Allievi et al., 2014; Jones et al., 2007; Lozano et al., 2011; Rojas-Pinzón \& Dussán, 2017). Namun, bakteri ini memiliki variasi tingkat toksisitas dan tidak semua strain L. sphaericus memiliki protein toksin tersebut.

Toksin yang sering ditemukan pada strain L. sphaericus dengan level toksisitas tinggi ialah binary toxin. Menurut Berry (2012), gen 
pengkode protein binary toxin sangat conserved di antara strain-strain yang telah diketahui. Variasi genetik pada binary toksin yang rendah mengakibatkan sedikitnya opsi toksin yang dapat digunakan (Hire et al., 2009). Sehingga penggunaan satu isolat $L$. sphaericus yang tidak terkendali menyebabkan reaksi resistensi terhadap target (Silva-Filha, et al., 2014). Hingga kini telah dilaporkan masalah resistensi dari $C$. quinquefasciatus terhadap Binary toxin. Oleh karena itu, perlu terus dikembangkan penelitian untuk mencari koleksi isolat baru yang menghasilkan toksin dengan efektivitas lebih tinggi dan dapat mengatasi permasalahan resistensi yang terjadi.

Penelitian yang dilakukan oleh Purwanto (2006) telah berhasil mengisolasi 1209 bakteri L. sphaericus yang diperoleh dari 418 sampel tanah dari berbagai wilayah di Indonesia. Salah satu di antaranya, yaitu isolat 229C, diketahui memiliki patogenisitas yang lebih tinggi dibanding strain pembanding 1593 ketika diujikan terhadap larva nyamuk $C$. quinquefasciatus (Indayati \& Purwanto, 2021). Namun, belum diketahui karakteristik molekular dan jenis toksin apa yang diproduksi oleh isolat ini.

Dalam rangka pengembangan isolat 229C sebagai potensial biolarvasida, perlu diketahui dan dipastikan identitas isolat tersebut serta posisinya dalam pohon filogenetik. Selain itu, perlu pula dilakukan analisis untuk mengetahui karakteristik molekular dan keberadaan toksinnya dengan menggunakan teknologi sekuensing genom. Hasil penelitian ini nantinya akan memberikan basis informasi mengenai koleksi isolat bakteri dengan toksin yang bersifat patogen terhadap nyamuk vektor dan memberikan alternatif pengendalian hayati untuk mengatasi permasalahan resistensi yang terjadi.

\section{Bahan dan Metode}

\section{Re-culturing, Perbanyakan, dan Preparasi Sampel}

Isolat 229C merupakan isolat yang sebelumnya dikoleksi dari tanah dan merupakan L. sphaericus berdasarkan pengamatan morfologi di bawah mikroskop fase kontras perbesaran 1000×. Proses re-culturing dilakukan dengan metode quadrant streak pada medium NA plate.
Koloni yang terpisah kemudian ditumbuhkan pada agar miring untuk kemudian diamati homogenitasnya di bawah mikroskop fase kontras perbesaran $1000 \times$ setelah $2 \times 24$ jam. Bakteri kemudian disiapkan untuk pengiriman ke MicrobesNG, Birmingham, UK sebagai pihak penyedia jasa sekuensing genom. Preparasi sampel dilakukan dengan cara mencampurkan isolat bakteri dengan $100 \mu \mathrm{l}$ larutan Ringer untuk ditumbuhkan pada $25 \mathrm{ml}$ medium NA pada plate dengan $1 / 3$ dari plate dipenuhi oleh bakteri hingga ditumbuhi dengan padat, sementara $2 / 3$ sisanya dicoretkan (streak). Setelah diinkubasi pada pertumbuhan yang sesuai, bakteri kemudian dipanen dan diletakkan pada barcoded tube yang telah disediakan oleh MicrobesNG, kemudian dikirimkan pada suhu ruang.

\section{Isolasi DNA dan Sekuensing Genom}

Proses selanjutnya yakni isolasi DNA dan tahap sekuensing genom yang dilakukan sesuai dengan ketentuan dan protokol yang ditetapkan oleh pihak penyedia jasa (MicrobesNG, n.d., 2018). Pada isolasi DNA, tiga beads dicuci dengan buffer ekstraksi yang mengandung lisozym dan RNAase A, kemudian diinkubasi selama 25 menit pada suhu $37^{\circ} \mathrm{C}$. Selanjutnya proteinase $\mathrm{K}$ dan RNAase A ditambahkan dan diinkubasi selama 5 menit pada $65^{\circ} \mathrm{C}$. DNA genom dimurnikan menggunakan volume yang sama dari beads SPRI dan diresuspensi dalam EB buffer. Pada tahap sekuensing genom, DNA dikuantifikasi dalam rangkap tiga dengan uji Quantit dsDNA HS dalam Ependorff AF2200 plate reader. DNA genom library selanjutnya disusun menggunakan Nextera XT Library Prep Kit (Illumina, San Diego, USA) Kemudian DNA genom library yang dikumpulkan dikuantifikasi menggunakan mesin Kapa Biosystems Library Quantification Kit for Illumina on a Roche light cycler 96 qPCR. DNA genom library diurutkan dengan Illumina HiSeq 2000 menggunakan protokol pair-end 250bp.

\section{Analisis Data \\ Penyusunan Contigs}

Genom yang telah disekuensing dengan menggunakan Illumina HiSeq 2000 sebagai layanan yang disediakan oleh MicrobesNG (Birmingham, UK) terlebih dahulu dipotong menggunakan Trimmomatic 0.30 dengan sliding 
window quality cutoff Q15 (Bolger et al., 2014). Tahap ini dilakukan untuk menghilangkan adapter yang terligasi di setiap ujung fragmen pada tahap pengurutan genom. Hasil pembacaan (reads) yang telah di-trim kemudian dinilai kualitasnya menggunakan skrip internal yang digabungkan dengan perangkat lunak, yaitu Samtools (Li et al., 2009), BedTools (Quinlan \& Hall, 2010) dan bwa-mem (Li \& Durbin, 2009). Potongan contigs selanjutnya disusun atau dirakit secara de novo (de novo assembled) menggunakan SPAdes versi 3.7 (Bankevich et al., 2012). Sementara assembly metrics yang berkaitan dengan satuan-satuan hasil penyusunan sekuens genom dihitung menggunakan QUAST (Gurevich et al., 2013).

\section{Anotasi Genom dan Analisis Toksin}

Anotasi genom dilakukan dengan tujuan mengidentifikasi elemen fungsional di sepanjang sekuen genom. Langkah ini dilakukan menggunakan RAST (Overbeek et al., 2014), dan Prokka 1.11 (Seemann, 2014). Hasil anotasi genom divisualisasikan dengan Artemis (Rutherford et al., 2000). Anotasi genom dengan Prokka dilakukan oleh pihak penyedia jasa sekuensing, sementara anotasi genom menggunakan RAST dilakukan melalui laman KBase (https://www./kbase.us) (Arkin et al., 2018). Berkenaan dengan aktivitas larvasidal, gen pengkodean binary toksin (BinA dan BinB), toksin Mtx (yang terkait dengan tahap vegetatif), kristal toksin (cry48/cry49), protein S-layer, hemolysin, dan gen chitin binding protein dideteksi dengan BLASTP dan COBALT Multiple Alignment pada laman NCBI (Krauthammer et al., 2000) serta MAUVE (Darling et al., 2004).

\section{Identifikasi Molekular dengan Gen 16S rRNA} Identifikasi molekuler dilakukan dengan menggunakan gen $16 \mathrm{~S}$ rRNA. Gen 16S rRNA didapatkan dengan cara memotong sekuen 16S rRNA hasil anotasi genom dengan bantuan Artemis (Rutherford et al., 2000). Sekuen gen 16S rRNA kemudian dianalisis menggunakan Nucleotide BLAST pada web NCBI (https://blast.ncbi.nlm.nih.gov/Blast.cg). Hasil analisis Nucleotide BLAST berupa similaritas dan identity yang menunjukkan kemiripan sampel dengan spesies yang ada pada database GenBank. Hasil yang didapatkan selanjutnya digunakan untuk memprediksi spesies dari sampel yang diteliti.

\section{Hasil dan Pembahasan}

\section{Morfologi Bakteri Isolat 229C}

Isolat bakteri 229C melalui proses pengamatan morfologis sebelum proses isolasi DNA dan sekuensing genom. Tahap ini dilakukan untuk membuktikan homogenitas dan kemurnian dari kultur bakteri. Hasil pengamatan tersebut ditampilkan pada Gambar 1.

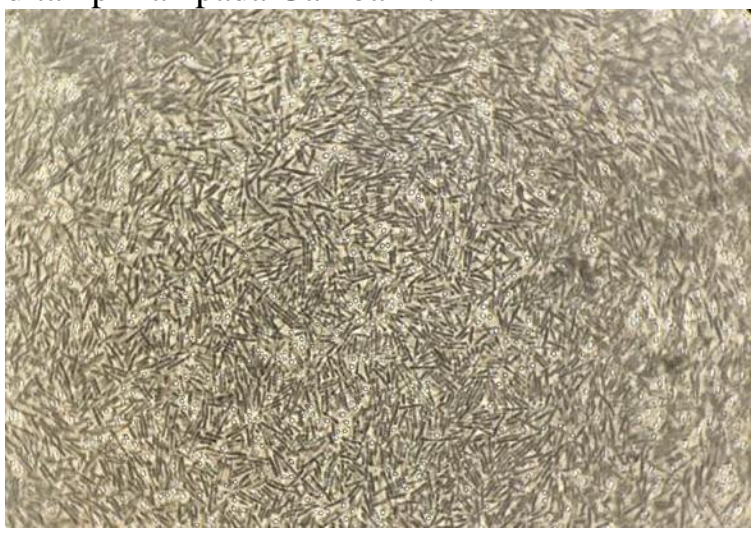

Gambar 1. Morfologi Isolat 229C ketika diamati dengan mikroskop fase kontras perbesaran 1000x.

\section{Karakteristik Genom dan Penilaian Kualitas Sekuensing}

Hasil sekuensing genom menunjukkan bahwa kualitas reads dan sekuens genom memenuhi syarat. Hal ini ditandai dengan tingginya nilai coverage dari isolat ini, yaitu $87 x$. Kualitas coverage data sekuens de novo tergantung pada ukuran dan kontinuitas dari contigs. Untuk sebuah studi whole genome sequencing, rekomendasi coverage yang dinyatakan dalam kualitas baik ialah 30-50× per genom (Illumina Inc., 2017).

Berdasarkan hasil penyusunan contigs, diketahui hasil sekuensing genom memiliki kualitas yang tergolong median hingga baik. Hal ini didasarkan pada nilai $\mathrm{G}+\mathrm{C}$ konten, jumlah contigs, ukuran genom, serta nilai N50, N75, L50, dan L75. Isolat 229C memiliki 36,83\% konten $\mathrm{G}+\mathrm{C}$ dengan total 119 contigs, dan ukuran genom 4,65 Mpb. Sedangkan nilai N50, N75, L50, dan L75 secara berurutan ialah 165,47; 79,98; 11; dan 20.

Selanjutnya sekuens melewati tahap anotasi genom yang bertujuan untuk mengidentifikasi elemen fungsional di sepanjang sekuen genom yang telah disusun di tahap sebelumnya. Informasi 
mengenai elemen-elemen fungsional yang teridentifikasi kemudian dibubuhkan pada sekuens yang selanjutnya disimpan dengan format genbank (.gbk) untuk kemudian divisualisasikan dengan Artemis. Hasil anotasi genom isolat 229C yang mencakup berbagai kategori fungsi disajikan pada Tabel 1.

Tabel 1. Hasil anotasi genom sampel isolat

\begin{tabular}{|c|c|}
\hline Statistik & 229C \\
\hline Jumlah Fitur/ Elemen Fungsional & 4685 \\
\hline CRISPR & 1 \\
\hline tRNA & 91 \\
\hline tmRNA & 1 \\
\hline Kode Genetik & 11 \\
\hline
\end{tabular}

\begin{tabular}{lr}
\hline \multicolumn{1}{c}{ Kategori Fungsional } & \\
\hline Karbohidrat & 287 \\
Respirasi & 38 \\
Nukleosida dan Nukleotida & 63 \\
Stress Response & 50 \\
Metabolisme Protein & 103 \\
Regulasi dan Cell Signaling & 25 \\
Dinding Sel dan Kapsul & 65 \\
Lain-Lain & 12 \\
Metabolisme RNA & 66 \\
Metabolisme Senyawa Aromatik & 48 \\
Clustering-Based Subsystems & 48 \\
Metabolisme Fosfor & 26 \\
Phages, Prophages, Transposable & \\
Elements & 1 \\
Metabolit Sekunder & 9 \\
Dormansi dan Sporulasi & 39 \\
Asam Amino dan Turunannya & 304 \\
Metabolisme Besi & 47 \\
Phages, Prophages, Transposable & \\
Elements, Plasmid & 6 \\
Pembelahan Sel dan Siklus Sel & 34 \\
Transpor Membran & 62 \\
Metabolisme Nitrogen & 16 \\
Metabolisme Sulfur & 17 \\
Metabolisme DNA & 69 \\
Kofaktor, Vitamin, Kelompok & \\
Prostetik, Pigmen & \\
Asam Lemak, Lipid, dan & \\
Isoprenoids & \\
\hline & \\
& \\
\hline
\end{tabular}

\begin{tabular}{lr}
\hline Virulensi, Disease, dan Defense & 38 \\
Metabolisme Potassium & 4 \\
Motilitas dan Kemotaksis & 71 \\
\hline
\end{tabular}

\section{Identifikasi Molekuler}

Sekuens 16S rRNA yang digunakan untuk identifikasi molekuler didapatkan dari sekuens genom isolat 229C. Sekuens genom isolat 229C diidentifikasi keberadaan gen $16 \mathrm{~S}$ rRNAnya kemudian dipotong pada sekuens tersebut dengan perangkat lunak Artemis. Sekuen 16S rRNA yang diperoleh tersebut selanjutnya dicari padanannya dari database genebank menggunakan online Nucleotide BLAST pada web NCBI (https://blast.ncbi.nlm.nih.gov/Blast.cgi). Dari hasil analisis didapatkan nilai query cover dan similaritas yang ditunjukkan dengan percent identity. Hasil analisis BLASTn disajikan pada Tabel 2.

\section{Analisis Gen Toksin}

Aktivitas larvasidal bakteri L. sphaericus terhadap $C x$. quinquefasciatus ditentukan oleh keberadaan gen toksin seperti $m t x$, bin, cry, sphaericolysin, S-layer protein, dan Hemolysin. Untuk mendeteksi dan mengidentifikasi gen-gen tersebut digunakan perangkat lunak MAUVE serta BLASTP dan COBALT Multiple alignment (pada laman NCBI). Hasil analisis menunjukkan bahwa pada isolat 229C tidak ditemukan keberadaan gen toxin $m t x$, bin, dan sphaericolysin. Akan tetapi, isolat ini diketahui memiliki toksisitas yang tinggi. Maka diduga terdapat gen toksin lain yang meningkatkan toksisitas isolat ini terhadap nyamuk vektor. Gen yang ditemukan pada isolat ini ialah S-layer protein dan Hemolysin yang diketahui berkontribusi pada toksisitas isolat (Allievi et al., 2014; Lozano et al., 2011; Rojas-Pinzón \& Dussán, 2017).

Berdasarkan anotasi genom, ditemukan gen pengkode s-layer protein pada isolat 229C. Hasil anotasi dengan RAST dan Prokka menunjukkan jumlah s-layer protein yang berbeda. Kemudian ketika dilakukan alignment dengan MAUVE, ditemukan bahwa terdapat sekuens serupa dengan gen s-layer protein pada genom referensi L.sphaericus C3-41 yang pada genom sampel penelitian teridentifikasi sebagai hypothetical protein berdasarkan hasil anotasi. 
Tabel 2. Hasil Analisis BLAST Gen Mitokondria 16S rRNA

\begin{tabular}{llllll}
\hline Isolat & $\begin{array}{c}\text { Sekuens terdekat } \\
\text { di GeneBank }\end{array}$ & $\begin{array}{c}\text { Accession } \\
\text { Number }\end{array}$ & $\begin{array}{c}\text { Query } \\
\text { Cover }\end{array}$ & Identity & \multicolumn{1}{c}{ Author } \\
\hline \multirow{2}{*}{ 229C } & L. sphaericus & NR_042073.1 & $96 \%$ & $100 \%$ & Swiderski, 2001 \\
& L. macroides & NR_114920.1 & $96 \%$ & $99.52 \%$ & Heyrman, 2005 \\
& L. fusiformis & NR_042072.1 & $96 \%$ & $99.37 \%$ & Swiderski, 2001 \\
& L. boronitolerans & NR_041276.1 & $94 \%$ & $99.51 \%$ & Ahmed, 2005 \\
& L. sphaericus & NR_115529.1 & $93 \%$ & $99.67 \%$ & Suzuki, 1993 \\
\hline
\end{tabular}

Sehingga apabila hasil alignment tersebut dihitung, total gen s-layer protein pada isolat 229C ialah 11 kopi. Rincian jumlah dan lokasi gen s-layer protein disajikan pada Tabel 3. Hasil analisis dengan bioinformatic tools berbeda menunjukkan jumlah yang berbeda pula. Hal ini terjadi karena setiap perangkat lunak menggunakan fitur dan metode yang berbeda dalam menganalisis genom sampel, baik dengan referensi maupun penyejajaran atau alignment.

Tabel 3. Jumlah dan lokasi gen s-layer protein hasil analisis dengan Prokka, RAST, dan MAUVE

\begin{tabular}{|c|c|c|c|c|c|c|}
\hline & \multicolumn{2}{|c|}{ Prokka } & \multicolumn{2}{|c|}{ RAST } & \multicolumn{2}{|c|}{ MAUVE } \\
\hline & Jumlah & Lokasi & Jumlah & Lokasi & Jumlah & Lokasi \\
\hline 2 & 1 & CDS & 8 & CDS.2185 & 11 & CDS_4036482 \\
\hline 2 & & 3236074 & & CDS.3280 & & CDS_4024245 \\
\hline 9 & & & & CDS.3299 & & CDS_3842034 \\
\hline C & & & & CDS.3319 & & CDS_2211401 \\
\hline & & & & CDS.3897 & & CDS_3456062 \\
\hline & & & & CDS.629 & & CDS_3236932 \\
\hline & & & & CDS.764 & & CDS_3259370 \\
\hline & & & & CDS.765 & & CDS_98204 \\
\hline & & & & & & CDS_4114984 \\
\hline & & & & & & CDS_714042 \\
\hline & & & & & & CDS_588929 \\
\hline
\end{tabular}

Berdasarkan anotasi genom isolat 229C, diketahui bahwa teridentifikasi gen pengkode hemolysin Hemolysin diketahui merupakan faktor virulensi penting dari bakteri entomopatogen yang meningkatkan efektivitas dari bakteri yang digunakan dalam pengendalian serangga (Andreeva et al., 2007; Manjeet et al., 2013). Hemolysin teridentifikasi pada 2 lokasi di genom isolat 229C. Kedua coding sequence tersebut kemudian dianalisis dengan BLASTP untuk memastikan sekuens terdekat dari urutan asam amino yang diduga Hemolysin ini pada database. Rincian lokasi gen yang diduga merupakan hemolysin serta hasil BLAST Protein masing-masing CDS disajikan dalam Tabel 4.

Tabel4. Hasil BLASTP (5 teratas) sekuens asam amino hemolysin isolat 229C

\begin{tabular}{llllll}
\hline No. & Description & Scientific Name & $\begin{array}{c}\text { Query } \\
\text { Cover }\end{array}$ & $\begin{array}{c}\text { Percent } \\
\text { Ident. }\end{array}$ & Acession number \\
\hline CDS_250508 & & & & \\
\hline 1. & $\begin{array}{l}\text { TlyA Family RNA } \\
\text { Methyltransferase }\end{array}$ & B. velezensis & $100 \%$ & $99.63 \%$ & WP_173479027.1 \\
2. & $\begin{array}{l}\text { MULTISPECIES: } \\
\text { TlyA Family RNA }\end{array}$ & Lysinibacillus & $100 \%$ & $98.16 \%$ & WP_024361173.1 \\
& $\begin{array}{l}\text { Methyltransferase } \\
\text { TlyA Family RNA } \\
\text { Methyltransferase }\end{array}$ & L. sphaericus & $100 \%$ & $97.79 \%$ & WP_069513091.1 \\
\hline
\end{tabular}


Viersanova \& Purwanto (2021). Jurnal Biologi Tropis, 21 (2): 576 - 586 DOI: http://dx.doi.org/10.29303/jbt.v21i2.2802

\begin{tabular}{llllll}
\hline 4. & $\begin{array}{l}\text { TlyA Family RNA } \\
\text { Methyltransferase }\end{array}$ & L. tabacifolii & $100 \%$ & $97.79 \%$ & WP_108029719.1 \\
5. & $\begin{array}{l}\text { TlyA Family RNA } \\
\text { Methyltransferase }\end{array}$ & L. varians & $100 \%$ & $97.79 \%$ & WP_025219921.1 \\
\hline CDS_4199394 & & & \\
\hline 1. & $\begin{array}{l}\text { Hemolysin III Family } \\
\text { Protein }\end{array}$ & B. velezensis & $100 \%$ & $98.58 \%$ & WP_172771607.1 \\
2. & $\begin{array}{l}\text { MULTISPECIES: } \\
\text { Hemolysin III Family }\end{array}$ & $\begin{array}{l}\text { Unclassified } \\
\text { Lysinibacillus }\end{array}$ & $100 \%$ & $87.20 \%$ & WP_053592763.1 \\
& $\begin{array}{l}\text { Protein } \\
\text { 3. }\end{array}$ & $\begin{array}{l}\text { Hemolysin III Family } \\
\text { Protein }\end{array}$ & L. xylanilyticus \\
4. & $\begin{array}{l}\text { Hemolysin III Family } \\
\text { Protein }\end{array}$ & L. xylanilyticus & $100 \%$ & $87.20 \%$ & WP_068984143.1 \\
5. & $\begin{array}{l}\text { Hemolysin III Family } \\
\text { Protein }\end{array}$ & $\begin{array}{l}\text { Lysinibacillus } \\
\text { sp. }\end{array}$ & $100 \%$ & $87.20 \%$ & WP_053485925.1 \\
\hline
\end{tabular}

\section{Morfologi Bakteri Isolat 229C}

L. sphaericus memiliki karakteristik morfologi yaitu berbentuk batang dengan spora berbentuk bulat (spherical) yang terdapat pada bagian terminal. Spora terletak di dalam sebuah sporangium yang membesar atau membengkak (Ahmed et al., 2007). Berdasarkan hasil pengamatan yang dilakukan, morfologi bakteri isolat 229C memiliki kesesuaian dengan morfologi bakteri L. sphaericus. Isolat ini memiliki morfologi sel yang berbentuk batang dengan spora berbentuk bulat di bagian terminal. Pengamatan dilakukan pada usia $2 \times 24$ jam dari kultur bakteri, sehinga dipastikan isolat bakteri sudah bertumbuh sporanya dan dapat teramati dengan jelas.

\section{Karakteristik Draft Genom dan Penilaian Kualitas Hasil Sekuensing}

Konten $\mathrm{G}+\mathrm{C}$ sampel bakteri $L$. sphaericus isolat $229 \mathrm{C}$ ialah $36,83 \%$. Nilai tersebut hampir memiliki kesamaan dengan strain referensi bakteri L. sphaericus yang biasanya memiliki konten $\mathrm{G}+\mathrm{C}$ dengan kisaran 37-38\%, seperti isolat C3-41 dengan kandungan $\mathrm{G}+\mathrm{C} 37,29 \%$ (Hu et al., 2008), strain L. sphaericus rekomendasi WHO 2362 dengan kandungan G + C 37,3\% (Hernández-Santana et al., 2016), strain OT4b.25 dengan kandungan $\mathrm{G}+\mathrm{C}$ $37,15 \%$ (Rey et al., 2016), strain dengan low level toxicity KCTC $3346^{\mathrm{T}}$ atau DSM 28 dengan kandungan $\mathrm{G}+\mathrm{C} 37,1 \%$ (Jeong et al., 2013), dan strain LMG22257 yang memiliki kandungan $\mathrm{G}+\mathrm{C}$ $38,99 \%$ (Yan et al., 2017).

Sekuens genom bakteri $L$. sphaericus isolat 229C memiliki ukuran 4,65 Mbp. Berdasarkan referensi studi whole genome sequencing pada strain referensi bakteri L. sphaericus, bakteri ini memiliki ukuran genom yang berkisar antara $4-5$
Mbp, seperti C3-41 yang berukuran 4, $64 \mathrm{Mbp}(\mathrm{Hu}$ et al., 2008), isolat referensi WHO 2362 yang berukuran 4,67 Mbp (Hernández-Santana et al., 2016), isolat metal tolerance CBAM5 yang berukuran 5,14 Mbp (Peña-Montenegro et al., 2015), strain entomopatogen OT4b.25 yang berukuran 4,66 Mbp (Rey et al., 2016), serta strain dengan low level toxicity terhadap larva nyamuk, KCT $3346^{\mathrm{T}}$ atau DSM28, yang berukuran $4,56 \mathrm{Mb}$ (Jeong et al., 2013). Berdasarkan uraian ini, diketahui bahwa isolat 229C memiliki karakteristik genom yang yang sesuai karakter bakteri $L$. sphaericus.

\section{Identifikasi Molekuler}

Tabel 2 menunjukkan 5 sekuens teratas yang ditunjukkan berdasarkan hasil analisis dengan BLASTn untuk setiap sampel isolat. Pengurutan tersebut didasarkan pada percent identity terbesar hingga terkecil dilanjutkan dengan query cover terbesar hingga terkecil. Berdasarkan hasil analisis tersebut, dari sampel sekuens gen 16S rRNA isolat 229C, diketahui memiliki similaritas yang paling tinggi dengan L. sphaericus. Percent identity mengacu pada pengukuran kuantitatif mengenai kesamaan antara dua urutan (baik DNA, asam amino, atau yang lainnya). Spesies yang berkerabat dekat memiliki percent identity yang lebih tinggi daripada spesies yang berkerabat lebih jauh. Dengan demikian, percent identity pada tingkat tertentu menunjukkan kedekatan atau keterkaitan (Quick \& Sikela, n.d.). Demikian halnya dengan query coverage. Query coverage menunjukkan persentase dari panjang kueri sekuens yang disertakan dalam alignment (Newell et al., 2013).

Pada studi mikrobioma modern, analisis urutan 16S rRNA sering digunakan dalam identifikasi taksonomi dari strain bakteri maupun 
archaea. Analisis ini menjadi standar de facto untuk taksonomi prokariotik. (Bukin et al., 2019). Sekuens 16S rRNA akan dikelompokkan berdasarkan similaritas-nya untuk menghasilkan Operational Taxonomy Unit (OTU) dan sekuens OTU representatif akan dibandingkan dengan database referensi untuk menyimpulkan kemungkinan taksonominya. Akan tetapi, analisis ini memerlukan asumsi tertentu untuk menginterpretasikan hasil analisisnya. Asumsi interpretasi similaritas yang diketahui saat ini ialah bahwa urutan identity $>95 \%$ mewakili kesamaan genus, sedangkan nilai identity $>97 \%$ mewakili spesies yang sama (Schloss \& Handelsman, 2005).

Pada hasil analisis dengan BLASTn diketahui bahwa isolat 229C memiliki $100 \%$ identity dengan L. sphaeriucs, sehingga dipastikan bahwa isolat ini merupakan jenis bakteri L. sphaericus. Namun, hasil BLASTn pada urutan kedua hingga kelima menunjukkan identity yang cukup besar yakni di atas $99 \%$, yang dapat dikatakan tidak berbeda secara signifikan. Berdasarkan pemaparan tersebut, diketahui bahwa pada hasil ini, ketentuan $>97 \%$ identity merepresentasikan organisme satu spesies menjadi tidak tepat. Karena identity $99 \%$ pada hasil BLASTn menunjukkan spesies yang beragam, mulai dari L. sphaericus, L. fusiformis, L. macroides, dan L. boronitolerans.

Gen 16S rRNA diketahui memiliki kurang lebih 1600 pasangan basa dan mencakup Sembilan daerah hipervariabel dengan berbagai sub-region (daerah) yang conserve, dinyatakan dengan V1 - V9. Sub-region yang lebih conserve berguna untuk menentukan tingkatan taksa yang lebih tinggi, sedangkan sub-region yang berevolusi lebih cepat dapat membantu mengidentifikasi pada tingkatan genus atau spesies (Bukin et al., 2019). Menurut Johnson et al. (2019), pilihan sub-region dapat mempengaruhi jumlah OTU yang terbentuk saat pengelompokan amplikon secara in-silico untuk membuat OTU. Jumlah relatif OTU yang dihasilkan untuk setiap sub-region tidak konsisten pada ambang nilai identity yang berbeda $(97 \%, 98 \%, 99 \%)$. Hal ini menunjukkan bahwa perilaku algoritma pengelompokan sulit diprediksi ketika jumlah informasi yang terkandung dalam sub-region yang diurutkan sangat bervariasi. Berdasarkan hal tersebut, dikatakan bahwa penargetan sub-region dengan
16S rRNA ini cukup untuk mewakili identifikasi taksa di tingkat genus atau di atasnya, tetapi untuk memprediksi spesies masih kurang valid. Meskipun beberapa sub-region diketahui memberikan hasil yang cukup masuk akal (V1V3), sebagian besar tidak bisa menangkap variasi urutan yang cukup untuk membedakan taksa yang terkait erat.

Setiap taksa memiliki perbedaan subregion yang cocok untuk dapat membedakannya, terutama pada taksa-taksa yang terkait erat (Johnson et al., 2019). Maka diketahui bahwa pada penelitian ini hasil identifikasi molekuler gen $16 \mathrm{~S}$ rRNA belum dapat mewakili identifikasi taksa di tingkat spesies. Anggota genus Lysinibacillus diketahui memiliki keterkaitan yang erat dan membutuhkan pemilihan subregion yang tepat untuk membedakan spesiesnya. Pada penelitian ini, dinyatakan bahwa sampel merupakan spesies $L$. sphaericus. Hal ini dikarenakan nilai identity yang mencapai $100 \%$. Untuk hasil lain, meskipun tidak signifikan berbeda, akan tetapi terdapat perbedaan basa nukleotida meskipun sangat sedikit. Mutasi pada bakteri terjadi sangat cepat karena pertumbuhannya yang juga sangat cepat. Untuk dapat mengetahui perbedaan antarspesies anggota genus Lysinibacillus selain melalui analisis morfologi dan molekuler ialah dengan analisis karakteristik biokimiawi. Namun, pada penelitian ini analisis karakteristik biokimiawi masih belum dapat dilakukan.

\section{Analisis Gen Toksin}

Berdasarkan analisis gen toksin, ditemukan gen pengkode S-layer protein pada isolat 229C. Peran patogen dari protein S-layer telah ditunjukkan pada bakteri $L$. sphaericus terhadap larva nyamuk $C$. quinquefasciatus dan Aedes aegypti (Allievi et al., 2014; Lozano et al., 2011). Pada fase sporulasi, spora $L$. sphaericus mempertahankan keberadaan protein S-Layer dan berasosiasi dengan Bin protein. Keberadaan toksin BinA-BinB dan protein S-Layer dalam spora suatu strain L. sphaericus berkontribusi terhadap patogenisitas L. sphaericus. Selain terdapat pada fase sporulasi $L$. sphaericus dan asosiasinya dengan protein toxin lain, protein $S$ layer juga terdapat pada fase vegetatif bakteri dan bersifat mosquitocidal meski tidak berasosiasi dengan protein toxin lainnya (Allievi et al., 2014). 
Protein S-Layer memiliki aktivitas hemolisis. Aktivitas ini menyebabkan terjadinya kerusakan membran sel target yang disebabkan oleh interaksi protein dengan lipid. Aktivitas hemolitik akan membantu efek patogenik protein S-Layer terhadap larva nyamuk dan diduga berkontribusi dalam menurunkan jumlah nyamuk resisten (Allievi et al., 2014).

Berdasarkan anotasi genom isolat 229C, diketahui bahwa teridentifikasi gen pengkode hemolysin. Hemolysin merupakan faktor virulensi penting dari bakteri entomopatogen yang meningkatkan efektivitas dari bakteri yang digunakan dalam pengendalian serangga (Andreeva et al., 2007; Manjeet et al., 2013).

Keberadaan hemolysin ditandai dengan keberadaan gen $h l y D$, hlyA, dan hly-III. Hasil BLASTP pada CDS yang terdeteksi sebagai hemolysin pada anotasi genom menunjukkan bahwa Hemolysin yang teridentifikasi pada setiap isolat bakteri merupakan Hemolysin A dan Hemolysin III, sedangkan Hemolysin D tidak teridentifikasi pada keempat isolat bakteri. Gen hlyD merupakan gen hemolysin yang berhubungan dengan sekresi protein hemolysin (Burgos \& Beutin, 2010). Berbeda dengan HemolysinD, HemolysinA atau rRNA methyltransferase TlyA (disingkat HlyA atau TlyA) adalah eksotoksin yang menyerang membran sel darah dan menyebabkan pecahnya sel yang disebabkan oleh natrium ribonukleat, dan umumnya diproduksi oleh strain bakteri patogen. Gen lainnya, hly-III, mengkode hemolysinIII memiliki berperan sebagai poreforming hemolysin (Baida \& Kuzmin, 1996).

Protein S-layer dan hemolysin diketahui memiliki keterkaitan dalam aktivitas entomopatogennya. Sebuah penelitian melaporkan adanya domain hemolitik dalam protein S-layer dan aktivitas larvasida dari protein tersebut dikaitkan dengan keberadaan domain tersebut (Allievi et al., 2014). Domain hemolitik yang berkaitan dengan protein s-layer dapat menjadi faktor toksik yang berkontribusi terhadap aktivitas entomopatogenik $L$. sphaericus (Rojas-Pinzón \& Dussán, 2017a). Adapun efek toksisitas dari hemolysin, setelah $L$. sphaericus dicerna oleh larva, bakteri mengenali reseptor spesifik dan melepaskan hemolysin yang melisiskan sel epitel midgut larva nyamuk, seperti yang terjadi. pada $C x$. quinquefasciatus dengan toksin Biner (Lekakarn et al., 2015).
Berdasarkan analisis toksin isolat 229C, diketahui bahwa pada isolat ini tidak ditemukan gen binary toksin yang diketahui sangat conserved pada strain dengan level toksisitas tinggi terhadap nyamuk. Namun, hasil anotasi genom yang dilanjutkan dengan analisis toksin dengan berbagai bioinformatics tools membuktikan bahwa pada sampel penelitian terdapat gen pengkode s-layer protein dan hemolysin. Keduanya merupakan gen yang terbukti memiliki aktivitas entomopatogen terhadap populasi nyamuk $C x$. quinquefasciatus yang resisten terhadap binary toksin dan $A$. aegypti (Allievi et al., 2014; Lozano et al., 2011; Rojas-Pinzón \& Dussán, 2017). Hasil ini menjadi penemuan yang prospektif sebagai pengembangan biolarvasidal potensial terhadap nyamuk vektor, $C x$. quinquefasciatus dan $A$. aegypti, di mana keduanya dikenal sebagai vektor berbagai penyakit yang merugikan. Selain itu, hasil ini juga menjadi jawaban atas permasalahan resistensi yang terjadi pada nyamuk $C x$. quinquefasciatus terhadap binary toksin yang diketahui sangat conserved pada $L$. sphaericus dengan high level toxicity. Penemuan ini juga membuka peluang dilakukannya penelitian lebih lanjut yang terfokus pada isolasi dan identifikasi terhadap s-layer protein dan hemolysin tersebut untuk mengetahui efektivitas toksin serta mekanisme kerjanya dalam mengakibatkan kematian pada larva nyamuk vektor penyakit.

\section{Kesimpulan}

Berdasarkan penelitian yang dilakukan, maka dapat disimpulkan bahwa hasil analisis genom menunjukkan 229C memiliki konten $\mathrm{G}+\mathrm{C} 36,83 \%$ dan ukuran genom 4.65 Mbp. Hasil identifikasi menunjukkan bahwa isolat 229C secara morfologis dan molekuler merupakan $L$. sphaericus. Berdasarkan analisis gen toksin yang dilakukan pada penelitian ini, diketahui bahwa pada isolat 229C tidak teridentifikasi adanya toksin Mtx, Bin, Cry, maupun sphaericolysin. Akan tetapi teridentifikasi adanya gen s-layer protein dan hemolysin. Keduanya diketahui merupakan gen yang memiliki aktivitas entomopatogen terhadap populasi nyamuk $C x$. quinquefasciatus yang resisten terhadap binary toksin serta $A$. aegypti yang diketahui merupakan vektor penyakit yang sangat merugikan pada 
manusia. Penemuan ini menjawab permasalahan resistensi yang terjadi pada $C x$. quinquefasciatus terhadap binary toxin. Selain itu, penemuan slayer protein dan hemolysin sebagai faktor toksisitas baru pada penelitian ini membuka peluang untuk penelitian lebih lanjut terhadap kedua gen tersebut sebagai toksin baru terhadap larva nyamuk.

\section{Ucapan terima kasih}

Penelitian ini dibiayai oleh Universitas Gadjah Mada melalui Program Rekognisi Tugas Akhir (RTA) 2020 yang diberikan kepada Hari Purwanto. Kami berterima kasih kepada kolega kami, Ika Indayati, dan seluruh staff Laboratorium Entomologi Fakultas Biologi, dan Laboratorium Mikrobiologi, Pusat Antar Universitas UGM, atas bantuannya selama penyusunan studi ini.

\section{Referensi}

Ahmed, I., Yokota, A., Yamazoe, A., \& Fujiwara, T. (2007). Proposal of Lysinibacillus boronitolerans gen. nov. sp. nov., and transfer of Bacillus fusiformis to Lysinibacillus fusiformis comb. nov. and Bacillus sphaericus to Lysinibacillus sphaericus comb. nov. International Journal of Systematic and Evolutionary Microbiology, 57(5), 1117-1125. https://doi.org/10.1099/ijs.0.63867-0

Allievi, M. C., Palomino, M. M., Acosta, M. P., Lanati, L., Ruzal, S. M., \& Sánchez-Rivas, C. (2014). Contribution of S-layer proteins to the mosquitocidal activity of Lysinibacillus sphaericus. PLoS ONE, 9(10).

https://doi.org/10.1371/journal.pone.0111 114

Andreeva, Z. I., Nesterenko, V. F., Fomkina, M. G., Ternovsky, V. I., Suzina, N. E., Bakulina, A. Y., Solonin, A. S., \& Sineva, E. V. (2007). The properties of Bacillus cereus hemolysin II pores depend on environmental conditions. Biochimica et Biophysica Acta - Biomembranes, 1768(2), 253-263. https://doi.org/10.1016/j.bbamem.2006.11 .004

Arkin, A. P., Cottingham, R. W., Henry, C. S.,
Harris, N. L., Stevens, R. L., Maslov, S., Dehal, P., Ware, D., Perez, F., Canon, S., Sneddon, M. W., Henderson, M. L., Riehl, W. J., Murphy-Olson, D., Chan, S. Y., Kamimura, R. T., Kumari, S., Drake, M. M., Brettin, T. S., ... Yu, D. (2018). KBase: The United States department of energy systems biology knowledgebase. Nature Biotechnology, 36(7), 566-569. https://doi.org/10.1038/nbt.4163

Baida, G. E., \& Kuzmin, N. P. (1996). Mechanism of action of hemolysin III from Bacillus cereus. Biochimica et Biophysica Acta - Biomembranes, 1284(2), 122-124. https://doi.org/10.1016/S00052736(96)00168-X

Bankevich, A., Nurk, S., Antipov, D., Gurevich, A. A., Dvorkin, M., Kulikov, A. S., Lesin, V. M., Nikolenko, S. I., Pham, S., Prjibelski, A. D., Pyshkin, A. V., Sirotkin, A. V., Vyahhi, N., Tesler, G., Alekseyev, M. A., \& Pevzner, P. A. (2012). SPAdes: A new genome assembly algorithm and its applications to single-cell sequencing. Journal of Computational Biology, 19(5), 455-477.

https://doi.org/10.1089/cmb.2012.0021

Berry, C. (2012). The bacterium, Lysinibacillus sphaericus, as an insect pathogen. Journal of Invertebrate Pathology, 109(1), 1-10. https://doi.org/10.1016/j.jip.2011.11.008

Bolger, A. M., Lohse, M., \& Usadel, B. (2014). Trimmomatic: A flexible trimmer for Illumina sequence data. Bioinformatics, 30(15), 2114-2120. https://doi.org/10.1093/bioinformatics/btu 170

Bukin, Y. S., Galachyants, Y. P., Morozov, I. V., Bukin, S. V., Zakharenko, A. S., \& Zemskaya, T. I. (2019). The effect of $16 \mathrm{~s}$ rRNA region choice on bacterial community metabarcoding results. Scientific Data, 6, 1-14. https://doi.org/10.1038/sdata.2019.7

Burgos, Y., \& Beutin, L. (2010). Common origin of plasmid encoded alpha-hemolysin genes in Escherichia coli. $B M C$ Microbiology, 10. https://doi.org/10.1186/1471-2180-10193

Darling, A. C. E., Mau, B., Blattner, F. R., \& 
Perna, N. T. (2004). Mauve: Multiple alignment of conserved genomic sequence with rearrangements. Genome Research, 14(7), 1394-1403. https://doi.org/10.1101/gr.2289704

Gurevich, A., Saveliev, V., Vyahhi, N., \& Tesler, G. (2013). QUAST: Quality assessment tool for genome assemblies. Bioinformatics, 29(8), 1072-1075. https://doi.org/10.1093/bioinformatics/btt 086

Hernández-Santana, A., Gómez-Garzón, C., \& Dussán, J. (2016). Complete genome sequence of Lysinibacillus sphaericus WHO reference strain 2362. Genome Announcements, 4(3), 9-10. https://doi.org/10.1128/genomeA.0054516

Hire, R. S., Hadapad, A. B., Dongre, T. K., \& Kumar, V. (2009). Purification and characterization of mosquitocidal Bacillus sphaericus BinA protein. Journal of Invertebrate Pathology, 101(2), 106-111. https://doi.org/10.1016/j.jip.2009.03.005

Hu, X., Fan, W., Han, B., Liu, H., Zheng, D., Li, Q., Dong, W., Yan, J., Gao, M., Berry, C., \& Yuan, Z. (2008). Complete genome sequence of the mosquitocidal bacterium Bacillus sphaericus C3-41 and comparison with those of closely related bacillus species. Journal of Bacteriology, 190(8), 2892-2902.

https://doi.org/10.1128/JB.01652-07

Illumina Inc. (2017). Illumina sequencing introduction. Illumina Sequencing Introduction, October, 1-8. https://www.illumina.com/documents/pro ducts/illumina_sequencing_introduction.p df

Jeong, H., Jeong, D. E., Sim, Y. M., Park, S. H., \& Choi, S. K. (2013). Genome sequence of Lysinibacillus sphaericus strain KCTC 3346T. Genome Announcements, 1(4), 4 5.

https://doi.org/10.1128/genomeA.0062513

Johnson, J. S., Spakowicz, D. J., Hong, B. Y., Petersen, L. M., Demkowicz, P., Chen, L., Leopold, S. R., Hanson, B. M., Agresta, H. O., Gerstein, M., Sodergren, E., \& Weinstock, G. M. (2019). Evaluation of $16 \mathrm{~S}$ rRNA gene sequencing for species and strain-level microbiome analysis. Nature Communications, 10(1), 1-11. https://doi.org/10.1038/s41467-01913036-1

Jones, G. W., Nielsen- Leroux, C., Yang, Y., Yuan, Z., Fiúza Dumas, V., Monnerat, R. G., \& Berry, C. (2007). A new Cry toxin with a unique two- component dependency from Bacillus sphaericus. The FASEB Journal, 21(14), 4112-4120. https://doi.org/10.1096/fj.07-8913com

Kellen, W. R., Clark, T. B., Lindegren, J. E., Ho, B. C., Rogoff, M. H., \& Singer, S. (1965). Bacillus sphaericus Neide as a pathogen of mosquitoes. Journal of Invertebrate Pathology, 7(4), 442-448. https://doi.org/10.1016/00222011(65)90120-5

Krauthammer, M., Rzhetsky, A., Morozov, P., \& Friedman, C. (2000). Using BLAST for identifying gene and protein names in journal articles. Gene, 259(1-2), 245-252. https://doi.org/10.1016/S0378-

1119(00)00431-5

Lekakarn, H., Promdonkoy, B., \& Boonserm, P. (2015). Interaction of Lysinibacillus sphaericus binary toxin with mosquito larval gut cells: Binding and internalization. Journal of Invertebrate Pathology, 132, 125-131. https://doi.org/10.1016/j.jip.2015.09.010

Li, H., \& Durbin, R. (2009). Fast and accurate short read alignment with BurrowsWheeler transform. Bioinformatics, 25(14), 1754-1760. https://doi.org/10.1093/bioinformatics/btp 324

Li, H., Handsaker, B., Wysoker, A., Fennell, T., Ruan, J., Homer, N., Marth, G., Abecasis, G., \& Durbin, R. (2009). The Sequence Alignment/Map format and SAMtools. Bioinformatics, 25(16), 2078-2079. https://doi.org/10.1093/bioinformatics/btp 352

Lozano, L. C., Ayala, J. A., \& Dussán, J. (2011). Lysinibacillus sphaericus S-layer protein toxicity against Culex quinquefasciatus. Biotechnology Letters, 33(10), 2037 2041. https://doi.org/10.1007/s10529011-0666-9

Manjeet, K., Purushotham, P., Neeraja, C., \& Podile, A. R. (2013). Bacterial chitin 
binding proteins show differential substrate binding and synergy with chitinases. Microbiological Research, 168(7), 461-468. https://doi.org/10.1016/j.micres.2013.01.0 06

MicrobesNG. (n.d.). MicrobesNg Methods Document. Microbesng.Com.

MicrobesNG. (2018). Preparing stock tubes for MicrobesNG. 6-7.

Newell, P. D., Roco, C. A., Fricker, A. D., Merkel, S. M., \& Chandrangsu, P. (2013). A Small-Group Activity Introducing the Use and Interpretation of BLAST $\dagger$. Journal of Microbiology \& Biology Education, 14(2), 238-243. https://doi.org/10.1128/jmbe.v14i2.637

Overbeek, R., Olson, R., Pusch, G. D., Olsen, G. J., Davis, J. J., Disz, T., Edwards, R. A., Gerdes, S., Parrello, B., Shukla, M., Vonstein, V., Wattam, A. R., Xia, F., \& Stevens, R. (2014). The SEED and the Rapid Annotation of microbial genomes using Subsystems Technology (RAST). Nucleic Acids Research, 42(D1), 206-214. https://doi.org/10.1093/nar/gkt1226

Peña-Montenegro, T. D., Lozano, L., \& Dussán, J. (2015). Genome sequence and description of the mosquitocidal and heavy metal tolerant strain Lysinibacillus sphaericus CBAM5. Standards in Genomic Sciences, 10(FEBRUARY2015). https://doi.org/10.1186/1944-3277-10-2

Quick, V. S., \& Sikela, J. (n.d.). Percent Identity of Genomic DNA and Amino Acid Sequences. Center for Academic Research and Training in Anthropogeny. Retrieved March 1, 2021, from https://carta.anthropogeny.org/moca/topic s/percent-identity-genomic-dna-andamino-acid-sequences\#: :text=Percent identity refers to a,to a degree reflects relatedness.

Quinlan, A. R., \& Hall, I. M. (2010). BEDTools: A flexible suite of utilities for comparing genomic features. Bioinformatics, 26(6), 841-842.

https://doi.org/10.1093/bioinformatics/btq 033

Rey, A., Silva-Quintero, L., \& Dussán, J. (2016). Complete genome sequence of the larvicidal bacterium Lysinibacillus sphaericus strain OT4b.25. Genome Announcements, 4(3), 10-12. https://doi.org/10.1128/genomeA.0025716

Rojas-Pinzón, P. A., \& Dussán, J. (2017). Contribution of Lysinibacillus sphaericus hemolysin and chitin-binding protein in entomopathogenic activity against insecticide resistant Aedes aegypti. World Journal of Microbiology and Biotechnology, 33(10), 0. https://doi.org/10.1007/s11274-017-23489

Rojas-Pinzón, P. A., \& Dussán, J. (2017b). Contribution of Lysinibacillus sphaericus hemolysin and chitin-binding protein in entomopathogenic activity against insecticide resistant Aedes aegypti. World Journal of Microbiology and Biotechnology, 33(10), 1-9. https://doi.org/10.1007/s11274-017-23489

Rutherford, K., Parkhill, J., Crook, J., Horsnell, T., Rice, P., Rajandream, M.-A., \& Barrell, B. (2000). Artemis: Sequence Visualization and Annotation. Bioinformatics, 16, 944-945.

Schloss, P. D., \& Handelsman, J. (2005). Introducing DOTUR, a computer program for defining operational taxonomic units and estimating species richness. Applied and Environmental Microbiology, 71(3), 1501-1506.

https://doi.org/10.1128/AEM.71.3.15011506.2005

Seemann, T. (2014). Prokka: Rapid prokaryotic genome annotation. Bioinformatics, 30(14), 2068-2069. https://doi.org/10.1093/bioinformatics/btu 153

Yan, W., Xiao, X., \& Zhang, Y. (2017). Complete genome sequence of Lysinibacillus sphaericus LMG 22257, a strain with ureolytic activity inducing calcium carbonate precipitation. Journal of Biotechnology, 246, 33-35. https://doi.org/10.1016/j.jbiotec.2017.02. 016 